\title{
THE INFLUENCE OF POLYPHENOLS ON THE FORMATION OF FREE RADICALS DETECTED IN MAILLARD REACTION MODEL SYSTEMS
}

\author{
Marijana B. Sakač ${ }^{1}$, Sonja M. Đilas ${ }^{2}$, Pavle T. Jovanov ${ }^{1}$ \\ ${ }^{1}$ University of Novi Sad, Institute of Food Technology, 21000 Novi Sad, Bulevar cara Lazara 1, Serbia \\ ${ }^{2}$ University of Novi Sad, Faculty of Technology, 21000 Novi Sad, Bulevar cara Lazara 1, Serbia
}

*Corresponding author:
Phone: +381214853772
Fax: +38121450725
E-mail address: marijana.sakac@fins.uns.ac.rs

\begin{abstract}
The formation of pyrazine cation radicals was detected in model systems consisted of D$(+)$-glucose $\left(1.0 \mathrm{~mol} \mathrm{~L}^{-1}\right)$ and structural isomers of aminobutanoic acid $\left(1.0 \mathrm{~mol} \mathrm{~L}^{-1}\right)$ heated at the temperature of $98^{\circ} \mathrm{C}$ for 20 minutes using electron spin resonance (ESR) spectrometry. Based on the analyses of hyperfine structure of ESR spectra of reaction mixtures of model systems, the presence of 1,4-disubstituted pyrazine cation radicals was found. Different polyphenols (gallic, caffeic, ferulic, chlorogenic acid, and tannic acid) were added in the model systems to investigate their influence on the formation of pyrazine cation radicals. It was found that tannic acid was the most efficient in inhibiting the formation of free radicals followed by gallic $>$ caffeic $\geq$ chlorogenic $>$ ferulic acid.
\end{abstract}

Key words: pyrazine cation radicals, polyphenols, ESR

\section{INTRODUCTION}

Browning reactions, which are some of the most important reactions occurring during food processing and storage, represent the phenomenon with significant implications in food technology, nutrition and health. The major groups of reactions resulting in browning are enzymatic and non-enzymatic browning. The latter is favoured by thermal treatment and includes different reactions such as Maillard reaction and caramelisation.

Maillard reaction occurs between the reactive carbonyl group of the sugar and the amino group of the amino acids to pro- duce compounds responsible for a range of odours and flavours in thermally treated foods (Abdullah, 2008).

It has been reported that Maillard reaction products possess certain antioxidant activity (Dittrich et al., 2003; Morales and Jimenez-Perez, 2001; Yoshimura et al., 1997). The highest antioxidant activity of Maillard reaction products is generally associated to the formation of melanoidins (Hayase et al., 1989; Yen and Hsieh, 1995; Manzocco et al., 2001). Therefore, increased antioxidant capacity of some functional bakery products was addressed 
not only to the presence of polyphenols present in the functional ingredients but to the antioxidant activity of Maillard reaction products which were formed during baking (Hsu at al., 2004). From that point of view, Maillard reaction is desirable for increasing overall antioxidant capacity of thermally treated products.

On the other hand, Maillard reaction is known for the formation of relatively stable free radicals in the initial stage of the reaction which were identified as 1,4disubstituted pyrazine cation radicals (Namiki and Hayashi, 1975; Hayashi et al., 1977; Hayashi and Namiki, 1986; Milić and Piletić, 1984). Kato and co-workers (1996) found that the reaction mixture of glucose and glycine in the initial stage of Maillard reaction showed characteristic multiline ESR signals due to the presence of 1,4di(carboxymethyl)pyrazine cation radical.

Pyrazine cation radical may be a key intermediate of imidazoquinoxaline-type mutagens in heated foods (Felton and Knize, 1991; Kikugawa et al., 2000), especially meat (Pearsons et al., 1992).

Food antioxidants, ascorbic acid and erythorbic acid effectively scavenged the pyrazine cation radicals generated in the reaction of glucose and glycine (Kikugawa et al., 2000). They could be scavenged by phenolic antioxidants including epigallocatehin gallate (Kato et al., 1996), cysteine and unsaturated fatty acids (Kikugawa et al., 1999). Furthermore, heterocyclic amines as the genotoxic carcinogens that were produced via pyrazine cation radical formation were affected by the addition of black or green tea, and of tea polyphenols theaflavine gallate and epigallocatechin gallate (Weisburger et al., 1994). Two flavonoids, luteolin and quercetin, and caffeic acid were found to suppress the formation of heterocyclic amines in cooked foods (Oguri et al., 1998).

Knowing that Maillard reaction may increase overall antioxidant activity of thermally treated foods and also provides pyrazine cation radicals that could deplete antioxidants, the aim of this work was directed to the investigation of the interaction of free radicals characteristic for Maillard rection with some polyphenols fre- quently contained in ingredients which are used in bakery production.

\section{MATERIAL AND METHODS}

\section{Model systems}

The formation of relatively stable free radicals in the initial stage of the Maillard reaction was carried out in following model systems:

I D-(+)-glucose (1.0 $\left.\mathrm{mol} \mathrm{L}^{-1}\right)$ - 2-aminobutanoic acid $\left(1.0 \mathrm{~mol} \mathrm{~L}^{-1}\right)$

II D-(+)-glucose $\left(1.0 \mathrm{~mol} \mathrm{~L}^{-1}\right)$ - 3-aminobutanoic acid $\left(1.0 \mathrm{~mol} \mathrm{~L}^{-1}\right)$ and

III D-(+)-glucose (1.0 mol L $\left.{ }^{-1}\right)$ - 4-aminobutanoic acid $\left(1.0 \mathrm{~mol} \mathrm{~L}^{-1}\right)$.

The $\mathrm{pH}$ value of model systems was adjusted to 9.0 using $0.1 \mathrm{M}$ potassium hydroxide and obtained mixtures were heated at the temperature of $98^{\circ} \mathrm{C}$.

The initial stage of the Maillard reaction was detected by detecting the formation of relatively stable free radicals after $20 \mathrm{mi}$ nutes (blank probe).

The influence of different polyphenols (gallic, caffeic, ferulic, chlorogenic acid, and tannic acid) on the formation of free radicals which are characteristic for the initial stage of the Maillard reaction was investigated by adding each polyphenol at the concentrations of $10^{-3}, 5 \cdot 10^{-3}, 10^{-2}$, $2.5 \cdot 10^{-2}, 5 \cdot 10^{-2}$ and $10^{-1} \mathrm{~mol} \mathrm{~L}^{-1}$ to the blank probe before heating.

Antiradical activity (AA in \%) of polyphenols was calculated according to the following equation:

$A A=100 \cdot\left(h_{0}-h_{x}\right) / h_{0}$

where $h_{0}$ and $h_{x}$ are the heights of the first peak in the ESR spectrum of free radicals of blank probe and probe, respectively.

\section{Detection of free radicals}

ESR spectra of generated free radicals in investigated Maillard reaction model systems were recorded using Bruker 300E ESR spectrometer (Bruker, Rheinstetten, Germany) under the following conditions: modulation field $100 \mathrm{kHz}$, modulation amplitude $1.021 \mathrm{G}$, receiver gain 103 , time constant $1.28 \mathrm{~ms}$, conversion time $5.234 \mathrm{~s}$, centre field $3440.00 \mathrm{G}$, sweep 
width $50.00 \mathrm{G}$, microwave frequency $9.65 \mathrm{GHz}$, microwave power $0.632 \mathrm{~mW}$, and temperature $(23 \pm 1){ }^{\circ} \mathrm{C}$.

A quartz flat cell Bruker ER-160FC was used for detection. Splitting constants were calculated from computer-generated second derivatives of the spectra after optimizing signal-to-noise ratios and were verified by computer simulations. ESR spectral files were imported into the WinSim program (WinSim, Sugar Land, TX, USA) for the analysis of the hyperfine splitting constants (Duling, 1994).

\section{RESULTS AND DISCUSSION}

The formation of relatively stable free radicals in alkaline reaction mixtures $(\mathrm{pH}$ 9.0) of the model systems consist of D-(+)glucose $(1.0 \mathrm{M})$ and structural isomers of aminobutanoic acid $(1.0 \mathrm{M})$ heated at the temperature of $98{ }^{\circ} \mathrm{C}$ for 20 minutes has been detected by ESR spectrometry. The ESR spectra of produced radicals in the initial stage of Maillard reaction are presented in Figure 1a and $b$.

The ESR spectrum presents in Fig. 1a con-sists of 19 lines of the relative intensities of $1: 2: 3: 2: 1$, characteristic for the presence of 1,4-disubstituted pyrazine cation radicals formed in both systems with the hyperfine coupling constants of $a_{N}$ $=8.73 \mathrm{G}$ and $\mathrm{a}_{\mathrm{H}}=2.81 \mathrm{G}$. After computer simulation of the ESR spectrum with these hyperfine coupling constants, the obtained simulated spectrum had the same appearance as the experimental spectrum.

In contrast to model systems I and II, ESR spectrum registered in model system III
(Figure $1 \mathrm{~b}$ ) is characterized by hyperfine coupling constants of two pyrazine nitrogens $\left(a_{N}=8.23 G\right)$, four equivalent pyrazine protons $\left(a_{H}=2.81 \mathrm{G}\right)$ and four equivalent side chain protons $\left(a_{H}=5.44 \mathrm{G}\right)$ confirming the formation of 1,4-disubstituted pyrazine cation radicals in the model system III.

These observations were consistent with the earlier results of Namiki and Hayashi (1975), Milić and Piletić (1984) and Rizzi (2004).

The addition of polyphenols in the concentration range from $10^{-3}$ to $10^{-1} \mathrm{~mol} \mathrm{~L}^{-1}$ in all investigated model systems (blank probes) affected the formation of 1,4-disubstituted pyrazine cation radicals. It was registered by decreasing of intensities of ESR signal.

The influence of gallic, caffeic, ferulic, chlorogenic acid, and tannic acid on the generation of pyrazine cation radicals is presented in Figure 2.

Phenolic compounds which are known as powerful antioxidants (Shahidi and Wanasundara, 1992) probably inhibited the generation of pyrazine cation radicals in alkaline media by a single electron transfer followed by conversion of phenolic compounds into phenoxyl radicals. The stabilization of phenoxyl radicals by resonance depends on the structure of antioxidants and influences their effectiveness.

The proposed mechanism could be confirmed by the results which were obtained using quinic acid in the defined concentration range $\left(10^{-3}-10^{-1} \mathrm{~mol} \mathrm{~L}^{-1}\right)$ to suppress the formation of pyrazine cation radicals in all model systems.
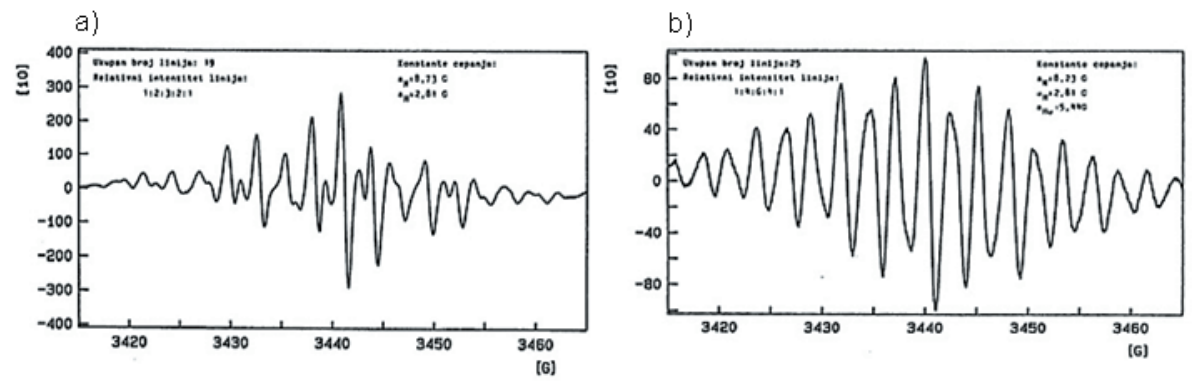

Figure 1. ESR spectra of reaction mixture heated at $98^{\circ} \mathrm{C}$ for 20 minutes

(a) of model systems I and II (2- or 3-aminobutanoic acid $\left(1.0 \mathrm{~mol} \mathrm{~L}^{-1}\right)$ and D-(+)-glucose $\left.\left(1.0 \mathrm{~mol} \mathrm{~L}^{-1}\right)\right)$ and

(b) of model system III (4-aminobutanoic acid $\left(1.0 \mathrm{~mol} \mathrm{~L}^{-1}\right)$ and $\mathrm{D}-(+)$-glucose $\left.\left(1.0 \mathrm{~mol} \mathrm{~L}^{-1}\right)\right)$ 

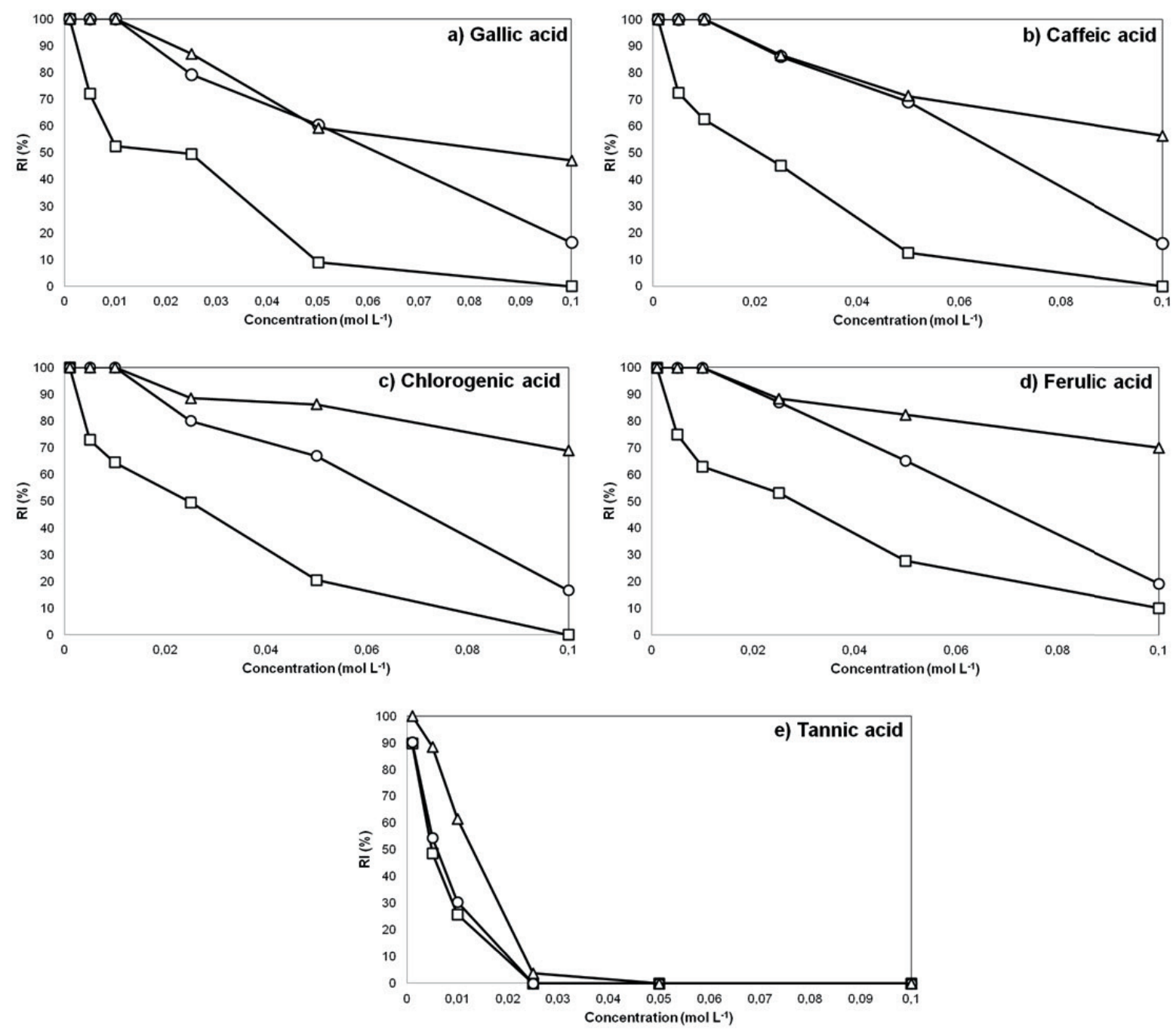

Figure 2. The influence of (a) gallic, (b) caffeic, (c) ferulic, (d) chlorogenic, and (e) tannic acid on the generation of 1,4-disubstituted pyrazine cation radicals formed in the initial stage of the Maillard reaction in model systems I ( $\square)$, II (०) and III ( $\Delta$ )

It was found that quinic acid, the moiety of chlorogenic acid, did not inhibit the formation of pyrazine cation radicals under all investigated conditions. That means that chlorogenic acid achieved its antiradical activity towards pyrazine cation radicals through its caffeoyl part via proposed mechanism.

The antiradical activity of polyphenols depends on the model system, as well as the type and concentration of polyphenols (Figure 2).

The effectiveness of investigated polyphenols to suppress the formation of pyrazine cation radicals in investigated model systems was in the following order: model system III > model system II > model system I. The established order could be explained by steric hindrance between pyrazine cation radical and polyphenol. Namely, pyrazine cation radical formed in the model system III possess four $\alpha$ protones in contrast to two a-protones bound to the pyrazine cation radical generated in model systems I and II. Therefore, the interaction between pyrazine cation radical and polyphenol in model system III could be easier and resulted in better suppression of formation of pyrazine cation radicals.

It was found that tannic acid was the most efficient of all investigated polyphenols in inhibiting the formation of free radicals in the initial stage of Maillard reaction followed by gallic $>$ caffeic $\geq$ chlorogenic $>$ 
ferulic acid. Effectiveness of investigated acids is the result of the abilities of formed phenoxyl radicals to stabilize by resonance. It was previously reported that gallic acid is much potent antioxidant that caffeic and chlorogenic acid due to its chemical features (Brand-Williams et al., 1995). Similar antiradical activities of caffeic and chlorogenic acids were due to their similar structures, i.e. chlorogenic acid reacts using its caffeoyl part as it is mentioned above.

Ferulic acid expressed the lowest antiradical activity towards pyrazine cation radicals among all investigated polyphenols, but was still active (Figure 2d). As this compound represents the major phenolic acid in many cereal products (LiyanaPathirana and Shahidi, 2007), its activity is very important, especially in bakery products.

Tannic acid was identified as the most potent inhibitor in formation of pyrazine cation radicals (Figure $2 e$ ). The ability of tannic acid to act as a potent suppressor was supported by the stability of tannic acid radicals which were detected by ESR (Fujita et al., 1988).

The involvement of polyphenols in the inhibition of formation of pyrazine cation radicals in the initial stage of Maillard reaction leads to the dilemma about contribution of Maillard reaction products in overall antioxidant capacity of thermally treated bakery products. Nevertheless, it is doubtless that polyphenols could scavenge pyrazine cation radicals and inhibit the formation of imidazoquinoxaline-type mutagens in heated foods.

\section{CONCLUSIONS}

It was found that polyphenols inhibit the formation of pyrazine cation radicals that were formed in the initial stage of Maillard reaction in heated alkaline reaction mixtures of model systems consisted of D-(+)glucose and structural isomers of aminobutanoic acid. The effectiveness of investigated polyphenols to suppress the formation of pyrazine cation radicals was in the following order: tannic > gallic > caffeic $\geq$ chlorogenic $>$ ferulic acid.

\section{ACKNOWLEDGEMENTS}

This paper is a result of the research within the projects TR31029 "Functional Cereal-based Products for People with Metabolic Disorders" and TR31014 "Development of New Functional Confectionery Products Based on Oilseeds" financed by the Ministry of Education, Science and Technological Development, Republic of Serbia.

\section{REFERENCES}

1. Abdullah, M.Z. (2008). Quality evaluation of bakery products. In Computer vision technology for food quality evaluation. Ed. D-W. Sun, Academic Press, Burlington, MA, USA, pp. 481481.

2. Brand-Williams, W., Cuvelier, M.E., Berset, C. (1995). Use of free radical method to evaluate antioxidant activity. LWT-Food Science and Technology, 28, 25-30.

3. Dittrich, R., El-Massry, F., Rinaldi, F., Peich, C. C., Beckman, M.W., Pischetsrieder, M. (2003). Maillard reaction products inhibit oxidation of human low-density lipoproteins in vitro. Journal of Agricultural and Food Chemistry, 51, 39003904.

4. Duling, D.R. (1994). Simulation of multiple isotropic spin-trap EPR spectra. Journal of Magnetic Resonance B, 104, 105-110.

5. Felton, J.S., Knize, M.G. (1991). Mutagen precursors in food: mutagen formation in muscle meats and model heating systems. In Mutagens in food: Detection and prevention. Ed. $\mathrm{H}$. Hayatsu, CRC Press, Boston, pp. 57-66.

6. Fujita, T., Komagoe, K., Niwa, Y., Uehara, I., Hara, R., Mori, H., Okuda, T., Yoshida, T. (1988). Studies of inhibition mechanism of autoxidation by tannins and flavonoids. Yakugaku Zasshi, 108, 528-537.

7. Hayase, F., Hirashima, S., Okamoto, G., Kato, $H$. (1989). Scavenging of active oxygen by melanoidins. Agricultural and Biological Chemistry, 53, 3383-3385.

8. Hayashi, T., Namiki, T. (1986). Role of sugar fragmentation in an early stage browning of amino-carbonyl reaction of sugar with amino acid. Agricultural and Biological Chemistry, 50, 1965-1970.

9. Hayashi, T., Ohta, Y. Namiki, M. (1977). Electron spin resonance spectral study on the structure of the novel free radical products formed by the reactions of sugars with amino acids or amines. Journal of Agricultural and Food Chemistry, 25, 1282-1287.

10. Hsu, C.-L., Hurang, S.-L., Chen, W., Wenig, Y.M., Tseng, C.-Y. (2004). Qualities and antioxidant properties of bread as affected by the incorporation of yam flour in the formulation. International Journal of Food and Science Technology, 39, 231-238.

11. Kato, T., Harashima, T., Moriya, N., Kikugawa, K., Hiramoto, K. (1996). Formation of the muta- 
genic/ carcinogenic imidazoquinoxaline-type heterocyclic amines through the unstable free radical Maillard intermediates and its inhibition by phenolic antioxidants. Carcinogenesis, 17, 2469-2476.

12. Kikugawa, K., Hiramoto, K., Kato, T., Yanagawa, H. (2000). Effect of food reductones on the generation of the pyrazine cation radical and on the formation of the mutagens in the reaction of glucose, glycine and creatinine. Mutation Research, 465, 183-190.

13. Kikugawa, K., Kato, T., Hiramoto, K., Takada, C., Tanaka, M., Maeda, Y., Ishihara, T. (1999). Participation of the pyrazine cation radical in the formation of mutagens in the reaction of glucose, glycine and creatinine. Mutation Research, 444, 133-144.

14. Liyana-Pathirana, C., Shahidi, F. (2007). Antioxidant and free radical scavenging activities of whole wheat and milling fractions. Food Chemistry, 101, 1151-1157.

15. Manzocco, L., Calligaris S., Mastrocola, D., Nicoli M.C., Lerici, C.R. (2001). Review of nonenzymatic browning and antioxidant capacity in processed foods. Trends in Food Science and Technology, 11, 340-346.

16. Milić, B.Lj., Piletić, M. (1984). The mechanism of pyrrole, pyrazine and pyridine formation in non-enzymatic browning reaction. Food Chemistry, 13, 165-180.

17. Morales, J.F., Jimenez-Perez, S. (2001). Free radical scavenging capacity of Maillard reaction products as related to colour and fluorescence. Food Chemistry, 72, 119-125.
18. Namiki, M., Hayashi, T. (1975). Development of novel free radicals during amino-carbonyl reaction of sugars and amino acids. Journal of Agricultural and Food Chemistry, 23, 487-491.

19. Oguri, A., Suda, M., Totsuka, Y., Sugimura, T., Wakabayashi, K. (1998). Inhibitory effects of antioxidants of formation of heterocyclic amines. Mutation Research, 402, 237-245.

20. Pearsons, A.M., Chen, C., Gray, J.I., Aust, S. D. (1992). Mechanism(s) involved in meat mutagen formation and inhibition. Free Radical in Biology and Medicine, 13, 161-167.

21. Rizzi, G. P. (2004). Free radicals in the Maillard reaction. Food Reviews International, 19, 375395.

22. Shahidi, F., Janitha, P.K., Wanasundara, P.D. (1992). Phenolic antioxidants. Critical Reviews in Food Science and Nutrition, 32, 67-103.

23. Weisburger, W.H., Nagao, M., Wakabayashi, K., Oguri, A. (1994). Prevention of heterocyclic amine formation by tea and tea polyphenols. Cancer Letters, 83, 143-147.

24. Yen, G.C., Hsieh, P. (1995). Antioxidative activity and scavenging effects on active oxygen of xylose-lysine Maillard reaction products. Journal of the Science of Food and Agriculture, 67, 415-420.

25. Yoshimura, Y., lijima, T., Watanabe, T., Nakazawa, H. (1997). Antioxidative effect of Maillard reaction products using glucose-glycine model system. Journal of Agricultural and Food Chemistry, 45, 4106-4109.

\title{
УТИЦАЈ ПОЛИФЕНОЛА НА СТВАРАЊЕ СЛОБОДНИХ РАДИКАЛА ДЕТЕКТОВАНИХ У МОДЕЛ СИСТЕМИМА МАILLARD-ОВИХ РЕАКЦИЈА
}

\author{
Маријана Б. Сакач*1 ${ }^{*}$ Соња М. Ђилас ${ }^{2}$, Павле Т. Јованов ${ }^{1}$ \\ ${ }^{1}$ Универзитет у Новом Саду, Научни институт за прехрамбене технологије у Новом Саду, 21000 \\ Нови Сад, Булевар цара Лазара бр. 1, Србија \\ ${ }^{2}$ Универзитет у Новом Саду, Технолошки факултет, 21000 Нови Сад, Булевар цара Лазара бр. \\ 1, Србија
}

Сажетак: Настајање пиразин катјон радикала детектовано је применом електрон спин резонантне (ECP) спектрометрије у модел системима који садрже D-(+)-глукозу $\left(1.0 \mathrm{~mol} \mathrm{~L}^{-1}\right)$ и структурне изомере аминобутерне киселине $\left(1.0 \mathrm{~mol} \mathrm{~L}^{-1}\right)$, загреваним на $98{ }^{\circ} \mathrm{C}$ током 20 минута. Анализом хиперфине структуре ЕСР спектара реакционих смеша испитиваних модел система установљено је настајање 1,4-дисупституисаних пиразин катјон радикала. Различита полифенолна једињења (гална, кафена, ферулна, хлорогенска и танинска киселина) додавана су у испитиване модел системе са циљем да се установи њихов утицај на стварање пиразин катјон радикала. Установљено је да је танинска киселина најефикаснија у инхибирању стварања слободних радикала, а ефикасност преосталих испитиваних полифенола опада према следећем редоследу: гална > кафена $\geq$ хлорогенска > ферулна киселина.

Кључне речи: пиразин катјон радикали, полифреноли, ЕСР

Received: 18 July 2018

Received in revised form: 4 September 2018

Accepted: 14 September 2018 